\title{
PERILAKU MENCONTEK SEBAGAI INDIKASI GAGALNYA EFIKASI DIRI (Self Efficacy) ANAK DALAM PEMBELAJARAN
}

\author{
Muhammad Nizaar \\ Dosen PGSD Universitas Muhammadiyah Mataram \\ nijadompu@gmail.com
}

\section{INFO ARTIKEL}

Riwayat Artikel:

Diterima: $25-11-2017$

Disetujui: 20 - 12 - 2017

\section{Kata Kunci:}

1. Perilaku Mencontek

2. Efikasi Diri (self efficacy)

\section{A. LATAR BELAKANG}

Dalam proses pendidikan di lingkungan sekolah tidak bisa dipungkiri terjadinya tindakan ketidakjujuran dalam memperoleh hasil belajar yang diharapkan. Salah satu sikap tidak jujur yang sering dijumpai dalam proses pembelajaran yaitu perilaku siswa mencontek pada saat proses ujian untuk memperoleh nilai yang maksimal.

Istilah mencontek tidak asing bagi kalangan dunia pendidikan. Masalah mencontek sering disandarkan pada nilai hasil ujian. Kadangkala dijumpai bahwa kebiasaan ini menjadi sesuatu yang lumrah dan dibiarkan begitu saja oleh guru sehingga jarang sekali menjadi suatu pembahasan dalam agenda evaluasi pembelajaran maupun evaluasi sekolah.

\section{ABSTRAK}

Abstrak: Kebiasaan mencontek dijumpai sebagai sesuatu yang lumrah dan dibiarkan begitu saja oleh guru sehingga jarang menjadi pembahasan dalam agenda evaluasi pembelajaran. Mencontek merupakan manifestation of using illegitimate means to achive a legitimate end. Permasalahan mencontek merupakan masalah yang serius karena akan terus terbawa sampai masuk dunia kerja sehingga dibutuhkan self efficacy yaitu kepercayaan diri dalam proses pembelajaran di kelas. Hal ini sangat penting karena self efficacy berfungsi sebagai; (1) membangun komitmen yang kuat, (2) mendorong untuk melakukan tindakan-tindakan terencana untuk meraih cita-cita, (3) memicu keberanian menghadapi tantangan tugas dan ujian, dan (4) menghindarkan anak dari sikap yang akan menggagalkan cita-cita. Perlu dilakukan pendekatan psikologis sesuai dengan konsep yang dikemukakan oleh Albert Bandura serta penanaman nilai karakter religiusitas self efficacy mengacu pada Al Qur'an Surat Ali Imran ayat 139. Kesempatan mencontek lahir dari ketidakwaspadaan pengawas serta adanya motivasi kondisi tertekan yang mengharuskan anak mendapat nilai bagus. Kebiasaan ini didukung pula oleh adanya dukungan media sosial dan website yang memberikan trik mencontek yang aman dan selamat, misalnya melalui facebook, limakaki.wordpress.com, munsypedia.com, caranyontek.blogspot.com, tololpedia.com, dll. Hasil kajian penulis, ada dua bentuk aktifitas belajar yang mengancam efikasi diri anak, yaitu; (1) guru sering memberikan hukuman yang membuat anak malu. Hukuman justru akan melahirkan legitimasi negatif sosial sebaya. Sebaiknya menggunakan hukuman sinaas apple yang diistilahkan oleh Jan Ligthart. (2) guru kurang menciptakan peluang siswa untuk aktif. Hal ini disebabkan adanya dominansi guru sebagai pemegang kontrol yang tidak ingin diganggu dengan pertanyaan dan respon siswa. Dengan demikian perlu adanya perubahan mind set guru, orangtua, dan lingkungan sosial sesuai dengan hasil kajian ini..

Kebiasaan mencontek lahir karena dorongan dari dalam diri siswa. Keyakinan yang mengakar pada siswa adalah nilai ujian harus maksimal sehingga mendorong siswa melakukan apapun agar nilainya baik walaupun diperoleh dengan cara tidak jujur. Mengatasi kebiasaan ini memang bukan perkara yang mudah. Menurut Bower (1964) bahwa mencontek (cheating) sebagai "manifestation of using illegitimate means to achive a legitimate end (achive academic or avoid academic failure)" maksudnya mencontek adalah perbuatan yang menggunakan cara-cara yang tidak sah untuk memperoleh keberhasilan akademis atau menghindari kegagalan akademis.

Dibutuhkan komitmen bersama baik guru, konselor, kepala sekolah, peserta didik dan orang tua untuk 
mengusahakan cara-cara konkret untuk menghilangkan ketergantungan anak pada perbuatan mencontek. Komitmen harus didasarkan pada pemahaman bersama bahwa dampak kebiasaan tidak jujur dalam memperoleh nilai akan terus terbawa sampai pada jenjang pendidikan berikutnya dan bahkan dalam dunia kerja nantinya.

Lawson (dalam Amriel, 2008) mengindikasikan bahwa siswa yang melakukan tindakan kebohongan akademik cenderung akan berbohong di tempat kerja. Kenyataanya, fenomena mencontek sangat serius terjadi. Kompleksitas yang terungkap dari temuan-temuan Barat tentang "kejahatan akademis" ini juga relevan dengan situasi dunia pendidikan Indonesia.

Penemuan tersebut sejalan dengan pendapat Haryono, dkk (2001), bahwa perilaku mencontek adalah perilaku yang sering dijumpai dalam dunia pendidikan. Perilaku ini adalah perilaku yang salah tetapi ada kecenderungan semakin ditolerir oleh masyarakat kita.

Salah satu sisi yang perlu disoroti dan sekaligus berhubungan langsung dengan penyebab kebiasaan mencontek yaitu karena proses pembelajaran gagal meyakinkan diri anak bahwa mereka telah memiliki kemampuan dalam menguasai suatu bahan kajian. Dalam ilmu psikologi keyakinan diri disebut efikasi diri. Efikasi diri adalah suatu keyakinan individu bahwa dirinya mampu untuk melakukan sesuatu dalam situasi tertentu dengan berhasil. Hal tersebut didasarkan pada pendapatnya Bandura (dalam Jess dan Feist, 2010) bahwa efikasi diri adalah keyakinan individu mengenai kemampuan dirinya dalam melakukan tugas dan tindakan yang diperlukan dalam melakukan suatu tugas. Perilaku mencontek muncul dikarenakan adanya ketidakyakinan akan kemampuan diri dalam meraih hasil yang optimal dengan usaha sendiri. Rendahnya keyakinan akan kemampuan diri (efikasi diri) ini membuat individu tidak mau berusaha dengan sungguhsungguh sehingga mendorong individu untuk melakukan cara yang lebih praktis yaitu mencontek. Dengan demikian pemahaman yang baik bagi para guru akan pentingnya memberikan keyanan pada diri siswa bahwa mereka telah mampu dan layak untuk diuji harus menjadi bagian dari proses pembelajaran.

Bagi penulis, masalah mencontek merupakan masalah bagi seluruh satuan pendidikan baik yang berlatar belakang agama maupun umum. Artinya walaupun dogma agama terhadap ketidakjujuran anak telah disampaikan namun belum mampu memberikan efek positif. Maka penulis menilai permasalahan mendasarnya terletak pada ketidakmampuan guru dalam membawa proses belajar pada pengaruh psikologis anak, yaitu rasa percaya diri menghadapi tantangan dan ujian.

\section{B. HASIL DAN PEMBAHASAN}

\section{Pengertian dan fungsi efikasi diri}

Dasar teori efikas diri dikembangkan dari teori kognitif sosial oleh profesor dari Universitas Stanford, Albert
Bandura (1977). Teori kognitif sosial berasumsi, setiap orang mampu menjadi agensi manusia, atau pekerjaan yang disengaja dari berbagai tindakan, dan beberapa agensi beroperasi dalam suatu proses yang disebut hubungan segitiga timbal balik yaitu pengaruh kondisi lingkungan, tingkah laku manusia, dan faktor pribadi seperti proses biologis dan kognitif.

Penulis menghubungkan efikasi diri dengan proses pembelajaran di sekolah karena dilihat dari fungsinya, menanamkan efikasi diri sangat penting. Meringkas dari pandangan Bandura, bahwa fungsi efikasi diri menyangkut hal-hal berikut:

a. Fungsi kognitif, semakin kuat efikasi diri anak akan memperkuat komitmen individu terhadap tujuan hidupnya misalnya dalam hal cita-cita.

b. Fungsi motivasi, mendorong anak untuk merencanakan tindakan-tindakan yang harus dilakukan untuk meraih masa depannya.

c. Fungsi sikap, menjadikan anak berani menghadapi tantangan dan konsekuensi yang akan terjadi dalam meraih tujuan yang diinginkan.

d. Fungsi selektif, mempengaruhi pemilihan aktifitas yang akan dilakukan individu agar mampu meraih suatu tujuan dan sekaligus menghindarkan diri dari hal-hal yang menjerumuskan diri pada kegagalan. Misalnya lingkungan yang buruk, kebiasaan buruk, maupun jaringan sosial.

Berdasarkan empat fungsi tersebut di atas maka dapat dimaknakan bahwa efikasi diri akan menjadi kendaraan emosional seseorang dalam meraih cita-cita yang sudah direncanakan. Lebih sederhannya, penulis deskripsikan dalam bentuk gambar berikut.

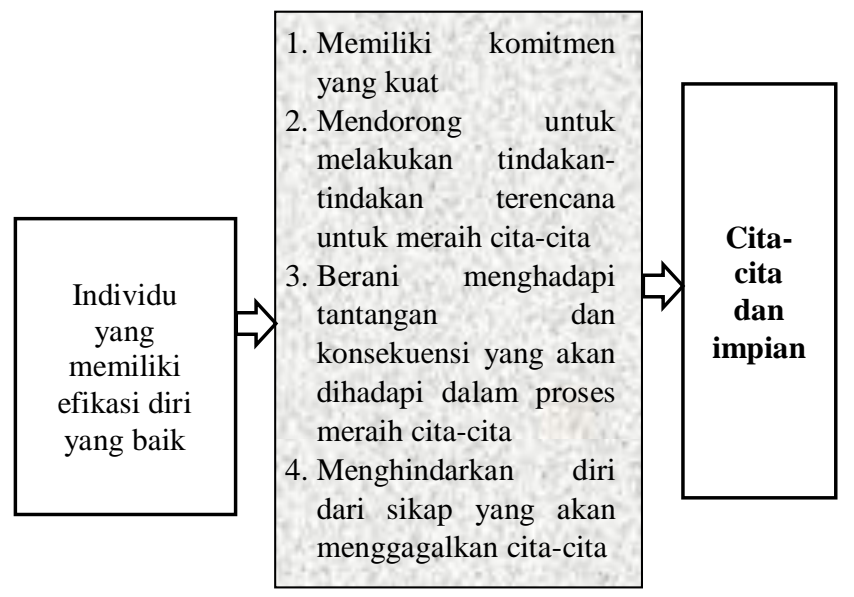

Menurut Bandura Hergenhahn \& Olson, 2008) orang yang memiliki kepercayaan diri tinggi akan berusaha lebih keras, meraih prestasi yang lebih banyak, dan lebih gigih. Hal ini dapat berarti sebaliknya, anak yang tidak memiliki kepercayaan diri yang baik dalam suatu kelas maka akan malas berusaha, berprestasi rendah, dan minder.

Harus diakui bahwa kemampuan setiap anak berbeda pada setiap bidangnya. Namun rasa malu, takut, dan merasa diri 
rendah akan membawa anak pada kondisi yang lebih parah dan berimbas pada mata pelajaran lain padahal anak mampu terhadap mata pelajaran yang lain tersebut. Perasaan rendah diri pada suatu bidang akan menjadikan anak minder pada semua bidang kecuali anak pindah di tempat lain yang dapat membangun kembali kepercayaan dirinya. Oleh karena itu, penulis menilai efikasi diri merupakan elemen yang sangat penting dalam meraih tujuan akhir dari suatu proses belajar di kelas.

\section{Bentuk-Bentuk Kebiasaan Mencontek Siswa di Kelas}

Kebiasaan adalah pengulangan sesuatu secara terusmenerus atau dalam sebagian besar waktu dengan cara yang sama dan dan sering terjadi secara otomatis. Mengacu pada Teori Behaviorisme John Broades Watson tentang terbentuknya perilaku dan kebiasaan memandang manusia sebagai produk lingkungan. Segala perilaku manusia sebagian besar dipengaruhi oleh lingkungan sekitarnya. Lingkunganlah yang membentuk kepribadian manusia.

Searah dengan pandangannya Watson di atas, Dollard \& Miller suatu kebiasaan lahir dari konteks sosial. Artinya suatu perilaku muncul pada tempat dimana lingkungan sosial memotivasinya. Maka dapat dimaknakan bahwa kebiasaan mencontek merupakan kebiasaan yang dilahirkan oleh kondisi kelas (pembelajaran) itu sendiri, yaitu kondisi aktivitas belajar yang tidak mendukung siswa berhasil dalam belajar.

Berdasarkan hasil observasi dan informasi, ada dua bentuk kebiasaan mencontek yang dilakukan siswa, yaitu:

a. Mencontek dengan usaha sendiri

Usaha sendiri disini dilakukan dengan mendesain catatan sendiri, membuka buku, membuat catatan kecil, menulis di tangan, bisa juga mencuri jawaban dari teman, diselipkan pada kaos kaki, pada kotak pensil, diselipkan pada kalkulator, dan mencontek lewat HP.

b. Mencontek secara bersama-sama

Kerja sama kadangkala dapat terbentuk karena adanya kekuatan persepsi bersama untuk memperoleh nilai dengan cara mencontek. Kesepakatan terlebih dahulu dibentuk dengan membuat kode-kode tertentu untuk meminta jawaban dari teman misalnya jawaban A dengan memegang jidat, jawaban $\mathrm{B}$ dengan garuk-garuk hidung, jawaban $\mathrm{C}$ dengan memegang kuping, dan jawaban $\mathrm{D}$ dengan memegang dagu. Hal ini sangat bergantung pada kesepakatan bersama.

Dari teori-teori motivasi, diketahui bahwa mencontek dapat terjadi apabila seseorang berada dalam kondisi tertekan (underpressure) atau apabila dorongan atau harapan untuk berprestasi jauh lebih besar daripada potensi yang dimiliki maka makin besar hasrat untuk mencontek. Dalam hal ini perilaku mencontek tinggal menunggu kesempatan.

Media-media yang tidak mendidikpun turut mendukung proses tumbuhnya kebiasaan mencontek, utamanya media internet. Beberapa website, blogg dan media sosial menshare kepada para pembacanya tentang bagaimana teknik mencontek yang aman dan selamat. Misalnya pada media sosial facebook, limakaki.wordpress.com, munsypedia.com,caranyontek.blogspot.com, tololpedia.wikia.com, dan masih banyak lagi.

\section{Menanamkan Karakter Percaya Diri Anak}

Kondisi degradasi moral saat ini berimplikasi pada perubahan orientasi pendidikan yang mensasarkan pada urgensi penanaman nilai karakter. Menurut Kemendiknas (2011) pendidikan karakter merupakan penanaman nilainilai karakter pada warga sekolah yang meliputi komponen pengetahuan (knowing), kesadaran/kemauan (feeling), dan tindakan (action) untuk melaksanakan nilai moral tersebut. Terdapat Sembilan pilar karakter yaitu: (1) Cinta Tuhan YME, (2) mandiri dan tanggung jawab (3) jujur dan amanah, (4) hormat dan santun, (5) suka tolong menolong, (6) percaya diri dan pekerja keras, (7) kepemimpinan dan keadilan, (8) baik dan rendah hati, (9) toleransi, kedamaian dan kesatuan.

Apabila ditinjau dari kesembilan pilar tersebut maka secara psikologis permasalahan kebiasaan siswa mencontek dapat disandarkan pada pilar percaya diri dan pekerja keras. Pendidikan yang bernuansa agama, secara dogmatis akan menanamkan salah satu kaidah berikut:

"Janganlah kamu bersikap lemah, dan janganlah kamu bersedih hati, padahal kamulah orang-orang yang paling tinggi derajadnya, jika kamu orang-orang yang beriman" (Ali Imran: 139).

Dari ayat tersebut tereksplisit tafsiran bahwa seseorang dalam menghadapi suatu urusan harus memiliki konsep diri (self concept) yaitu memahami potensi diri (kekuatan) sehingga membangkitkan rasa percaya diri. Dapat dimaknakan kebiasaan mencontek merupakan wujud dari kegelisahan dan kehawatiran anak ketika menghadapi proses ujian. Penanaman dogma ayat di atas tidak hanya cukup ditanamkan dalam bentuk lisan namun harus terimplikasi pada proses pembelajaran dengan membangkitkan psikologis anak.

\section{Membangun Efikasi Diri dalam Pembelajaran}

Membangun efikasi diri dapat dilakukan secara integral bersama proses pembelajaran. Guru perlu menyadari dengan baik bahwa setiap anak memiliki sisi potensi untuk berkembang serta sisi potensi untuk gagal. Tergantung kondisi pembelajaran yang dialami anak. Dengan demikian aktifitas pembelajaran seyogyanya membawa ke arah yang positif sehingga mendukung kepercayaan diri anak yang bermuara pada keberhasilan belajar.

Hasil kajian penulis, ada dua bentuk aktifitas belajar yang mengancam efikasi diri siswa, yaitu:

a. Sering memberikan hukuman yang membuat anak malu Beberapa kasus guru yang menghukum siswanya masih teringat kasus guru yang mencubit siswanya dan hakim menetapkan sang guru bersalah dan menjatuhkan vonis 
denda 20 juta dengan subside hukuman 1 bulan penjara. Lalu ada pula kasus penamparan oleh guru terhadap siswai SD Harmoni di Batam. Dikatakan bekas tamparan tersebut meninggalkan luka lebam di pipi sehingga anak trauma ke sekolah. Kasus yang sama juga pernah terjadi di SMK Gajah Mungkur 1, oknum guru diduga melakukan penamparan terhadap seorang siswa karena korban melanggar disiplin saat upacara bendera.

Dari beberapa contoh kasus, dasar tindakan guru yaitu bermaksud memberikan hukuman kepada anak karena telah melanggar peraturan dan ataupun karena tidak mampu melaksanakan tugas seperti yang guru minta. Namun kebanyakan diakhiri dengan penetapan guru sebagai tersangka dan dijatuhi hukuman penjara dan denda.

Guru sebenarnya memiliki kebebasan dalam memberikan sanksi kepada peserta didik yang tidak patuh dan sudah diatur dalam UU No. 14 Tahun 2005 Pasal 39 tentang penilaian, penghargaan, dan sanksi oleh guru kepada peserta didik. Perlu adanya kejelasan persepsi tentang pemberian hukuman yang tepat.

Menurut Skiner (Hergenhahn \& Olson, 2008) hukuman sebenarnya tidak efktif untuk menghindarkan anak pada perbuatan yang keliru, tidak akan mampu menekan perilaku, apabila ancaman hukuman hilang maka kecenderungan perbuatan tersebut akan diulang lagi, hanya menghasilkan efek temporer. Efek yang paling membahayakan dari hukuman yaitu lahirnya legitimasi sosial sebaya bahwa anak tersebut bodoh, malas, pembangkang, dan nakal sehingga memberikan efek malu yang berdampak pada ketidakpercayaan diri anak. Hukuman yang baik yaitu hukuman yang bersifat mendidik dan diusahakan relevan dengan kesalahan yang dilakukan anak.

Salah satu hukuman yang menarik yaitu hukuman yang diistilahkan oleh Jan Ligthart yaitu sinaas appel yang sering dimaknakan sebagai hukuman jeruk manis, anak tidak perlu dihukum tetapi didekati dan diambil hatinya, komunikasikan permasalahannya dengan baik layaknya orangtua dan anak.

b. Kurang menciptakan peluang untuk aktif

Penulis menggunakan istilah menciptakan peluang. Salah satu indikatornya yaitu anak distimulus untuk bertanya. Bertanya adalah cara untuk mengungkapakan rasa keingintahuan akan jawaban yang tidak atau belum diketahui. Fakta yang terjadi adalah masih banyak dari siswa yang justru diam membisu ketika guru bertanya atau memberikan kesempatan untuk bertanya di kelas. Salah satu penelitian yang dilakukan oleh Soufia (2003) untuk mata pelajaran IPS di SMP Muhammadiyah 2 Surakarta berkomunikasi dalam bentuk pertanyaan masih sangat jarang dilakukan. Hasil analisisnya pada table berikut.

\begin{tabular}{|l|l|}
\hline Aspek Aktifitas & Porsentase \\
\hline Kesiapan menerima pelajaran & $43,24 \%$ \\
\hline Mempersiapkan tugas/PR & $27,07 \%$ \\
\hline Konsentrasi penuh & $35,13 \%$ \\
\hline Mencatat hasil pembahasan & $32,43 \%$ \\
\hline Mengajukan pertanyaan & $\mathbf{2 , 7 \%}$ \\
\hline $\begin{array}{l}\text { Mengemukakan pendapat, ide, } \\
\text { gagasan }\end{array}$ & $8,10 \%$ \\
\hline Memperhatikan penjelasan guru & $35,13 \%$ \\
\hline
\end{tabular}

Perasaan malu atau takut untuk bertanya yang terjadi saat siswa masih duduk di bangku sekolah bukannya tidak mungkin akan berlanjut sampai ia dewasa. Karena pada dasarnya kebiasaan yang ditanam sejak kecil, biasanya akan membentuk pola pikir yang sama saat ia telah dewasa nanti. Hal ini sejalan dengan teori operant conditioning dari Skinner (dalam Santrock, 2008), dimana ia mengatakan bahwa pemberian reinforcement (positif atau negatif) dapat mengakibatkan terbentuknya perilaku yang diharapkan atau yang tidak diharapkan yang dapat berlangsung lama.

Siswa akan jarang bertanya di kelas ketika guru tidak atau jarang memberikan kesempatan pada siswa untuk bertanya. Guru merasa dirinya sebagai pemegang kontrol penuh atas kelas, sehingga guru tersebut merasa tidak ingin diganggu oleh pertanyaan-pertanyaan siswa.

\section{SIMPULAN DAN SARAN}

Kebiasaan mencontek lahir dari adanya kehawatiran anak terhadap hasil ujian yang rendah sehingga anak akan berupaya semaksimal mungkin untuk memperoleh nilai yang baik walaupun dilakukan dengan cara yang tidak jujur yaitu menyontek. Secara psikologis sebenarnya anak yang terbiasa mencontek disebabkan karena hilangnya kepercayaan diri terhadap kemampuannya. Hal ini sangat beralasan karena fungsi kepercayaan diri dalam pembelajaran yaitu membangun komitmen yang kuat, mendorong untuk melakukan tindakan-tindakan terencana untuk meraih cita-cita, memicu keberanian menghadapi tantangan dan konsekuensi yang akan dihadapi dalam proses meraih citacita, dan menghindarkan anak dari sikap yang akan menggagalkan cita-cita.

Guru perlu membangun kepercayaan diri anak dalam pembelajaran dengan mengedepankan dua hal yaitu (1) hindari pemberian hukuman yang tidak relevan karena hal itu akan melahirkan efek legitimasi sosial sebaya yang membuat anak malu sehingga anak menjadi minder dan pendendam, sebaiknya menggunakan hukuman sinaas apple yaitu melakukuan pendekatan dan dikomunikasikan permasalahannya. (2) ciptakan peluang untuk aktif dalam proses pembelajaran. Peluang harus diberikan secara merata agar anak yang merasa minder dapat bangkit kepercayaan dirinya. 
Selain dua hal tersebut, untuk mendukung hilangnya kebisaan mencontek maka sesara social, masyarakat dan orangtua juga harus menyadarkan anak bahwa tindakan tersebut keliru. Secara tidak langsung bentuk dukungan langsung masyarakat terhadap tindakan menyontek ini yaitu sikap tidak peduli dan pembiaran terhadap anak terhadap kebiasaan mencontek serta adanya media masa dan informasi yang memberikan penjelasan cara dan teknik mencontek yang aman dan selamat.

\section{DAFTAR RUJUKAN}

[1] Armstrong, Thomas. 2002. Setiap Anak Cerdas . Panduan Membantu Anak Memanfaatkan Multiple Intelegence (terj.). Jakarta: PT. Gramedia Pustaka Utama.

[2] Hergenhahn \& Olson. 2008. Teories of Learning (terj.) oleh Tri Wibowo. Jakarta: Kencana Prenada Media Group.

[3] Triantoro Safaria. 2008. Successful Intelligence. Yogyakarta: Arti Bumi Intaran.

[4] Jess dan Gregory J. Feist. 2010. Teories of Personality (terj.) oleh Smita Prathita Sjaputri. Jakarta: Salemba Humanika.

[5] Susanto Andrian. UU Perlindungan Anak: Derita Guru. http://edukasi.compasiana.com/2012/11/08/uuperlindungan-anak-derita-guru.html. 